\title{
MACHADO DE ASSIS E A IMPRENSA PERIÓDICA: UMA ANÁLISE DE “CONFISSÕES DE UMA VIÚVA MOÇA"
}

\author{
Greicy Bellin \\ Universidade Federal do Paraná
}

Resumo: O presente artigo tem por finalidade analisar o conto "Confissões de uma viúva moça", publicado por Machado de Assis em formato de folhetim no periódico Jornal das Famílias. O conto evidencia como Machado atuou na imprensa periódica do Rio de Janeiro no início de sua carreira literária, bem como a maneira pela qual se relacionou com os seus leitores, fossem eles empíricos ou ficcionais. Em primeiro lugar, será feita uma breve preleção teórica a respeito do estatuto do jornal e da formação do público leitor na sociedade brasileira oitocentista, procurando compreender o papel dos periódicos na publicação e circulação de obras literárias e o perfil dos leitores do Jornal das Famílias. Em segundo lugar, faremos a análise do conto machadiano, a fim de mostrar como se dá a construção de um relacionamento entre leitor empírico e narrador, considerando o veículo em que a narrativa foi publicada. Por último, será feita uma análise a respeito da polêmica surgida no Correio Mercantil na época da publicação de "Confissões de uma viúva moça", com o objetivo de mostrar como Machado e seu editor se relacionavam com os leitores das narrativas publicadas no Jornal das Famílias.

Palavras-chave: Jornal. Folhetim. Público leitor.

\section{Introdução}

O objetivo do presente artigo é analisar o conto "Confissões de uma viúva moça", de Machado de Assis, a fim de esmiuçar como se deu a colaboração do escritor na imprensa periódica de sua época, bem como o relacionamento estabelecido com o público leitor dos folhetins que ele publicava no Jornal das Famílias, um dos periódicos de maior circulação no Rio de Janeiro do século XIX. Com base nesta análise, mostraremos que Machado tinha uma aguda consciência em relação à presença do leitor na significação de uma obra literária, principalmente se levarmos em consideração a polêmica, surgida no Correio Mercantil,

Esta obra está licenciada sob uma Licença Creative Commons.

\footnotetext{
* Possui mestrado em literatura norte americana e estudos de gênero pela UFPR (2010). Atualmente é doutoranda em literatura comparada pela mesma instituição. Tem experiência na área de Letras, com ênfase em literatura brasileira e norte americana, e estudos feministas e de gênero, além de prática de ensino em língua inglesa. Atuou como professora no Centro de Línguas da UFPR. E-mail: grebellin@yahoo.com.br.
} 
quando da publicação da narrativa a ser analisada, que teria causado revolta por conter um caráter subversivo em relação à moral burguesa e aos costumes da família brasileira oitocentista.

No Brasil do século XIX, o jornal era o principal meio de comunicação de massa, exercendo um papel importante na publicação e circulação de obras literárias. Segundo Hélio de Seixas Guimarães, “o principal veículo de escoamento da produção literária oitocentista era o jornal, sendo raro o romance publicado em volume sem antes ter passado pelo rodapé dos diários cariocas.” (GUIMARÃES, 2004, p. 49). A popularidade e o alcance do jornal eram perfeitamente compreensíveis em um contexto marcado pelo analfabetismo e por um baixo poder aquisitivo, que tornava difícil ou até mesmo inviabilizava a aquisição de obras literárias. Para se ter uma ideia, em 1872 apenas 18\% da população brasileira livre era alfabetizada, número este que baixou para 14\% em 1890. Na mesma época, Inglaterra e França contavam, respectivamente, com 70 e $77 \%$ de alfabetizados, ao passo que os Estados Unidos, nação de independência recente, contava com quase $90 \%$ de população branca alfabetizada. (GUIMARÃES, 2004, p. 64). Estes dados nos ajudam a compreender a existência de um enorme abismo entre público leitor e produção de cultura letrada, o que impactava diretamente a circulação de textos literários, que encontravam no jornal uma forma prática e eficaz de atingir a pequena parcela alfabetizada da população brasileira.

A imprensa periódica era também a porta de entrada da maioria dos escritores brasileiros na esfera da produção ficcional. Machado de Assis foi um deles, tendo iniciado suas colaborações na Marmota Fluminense, onde trabalhou primeiro como caixeiro, depois como tipógrafo e por fim, como colunista. Machado também colaborou no Diário do Rio de Janeiro, onde exerceu atividade como crítico teatral, além de elaborar comentários contundentes em relação à situação política da época. Sua colaboração no Jornal das Famílias, no entanto, foi a mais relevante, tendo se estendido de 1864 a 1878. Machado publicou quase uma centena de narrativas no periódico ao longo deste período, narrativas estas que eram, em sua maioria, de cunho romântico e sentimental, destinadas a provocar a emoção das leitoras. Neste sentido, faz-se necessário analisar como se deu a configuração de um público leitor e de um perfil ideológico específicos, a fim de compreender como surgiu a polêmica relacionada ao conto "Confissões de uma viúva moça".

O Jornal das Famílias surgiu em 1859 sob o nome de Revista Popular, tendo como editor o francês Baptiste Louis Garnier. Para Hélio de Seixas Guimarães, 
Garnier foi figura fundamental para a definição do mercado real das publicações brasileiras por ter sido o primeiro editor a publicar sistematicamente autores nacionais, tendo lançado 655 trabalhos de autores brasileiros no período 1860-1890, além de muitas traduções de autores estrangeiros. (GUIMARÃES, 2004, p. 95).

No tocante à carreira literária de Machado de Assis, Garnier foi também imprescindível, uma vez que publicou em livro os primeiros romances machadianos antes de lançá-los em folhetim, o que seria o usual na época. Destaca-se, portanto, a importância da mediação estrangeira na formação da cultura e da literatura brasileira oitocentistas, ainda mais se considerarmos que o Jornal era impresso em Paris, "o que favorecia o barateamento da assinatura, melhorava a qualidade da impressão e representava mais prestígio para o periódico, já que, no Brasil desse período, havia uma supervalorização de tudo o que vinha da França." (FARIAS, 2013, p. 83).

Em 1863, o periódico mudou de nome devido a mudanças em sua estruturação e direcionamento, passando a apresentar seções mais restritas, "com um enfoque predominantemente literário e voltado exclusivamente para o público feminino e para os interesses domésticos das famílias brasileiras.” (CRESTANI, 2006, p. 148). O elemento marcante das publicações era a preocupação com a instrução moral, bem como o caráter religioso, o que fazia com que a literatura publicada neste periódico fosse romântica e de caráter fantasioso. Assim sendo, os textos publicados no Jornal ajudavam na perpetuação de uma ideologia burguesa, que visava manter a integridade do lar e da família, defendendo a necessidade de ministrar uma educação decente às mulheres. Com base em tais informações, parece-nos certo considerar que Machado de Assis, como um dos principais colaboradores do periódico, sofresse uma pressão, por parte de seu editor, para se adequar ao perfil do público leitor, constituído, em sua imensa maioria, por mulheres provenientes de famílias conservadoras da sociedade carioca. Para Jaison Crestani, o escritor era colocado "no fio da navalha", isto é, "na obrigação de não escandalizar o pai ou marido que pagava pela assinatura do jornal, e, ao mesmo tempo, seduzir a mulher que o lia." (CRESTANI, 2006, p. 152). Todavia, Crestani reconhece a existência de traços subversivos e corrosivos que transgrediam os padrões estabelecidos pelo periódico, a partir dos quais Machado já articulava, mesmo antes da fase realista, "o seu pensamento crítico em relação aos mecanismos que governavam a sociedade brasileira da época." (CRESTANI, 2006, p. 156). Isto se torna visível em "Confíssões de uma viúva moça", na narração de um episódio de infidelidade entre uma mulher casada e um homem de moral duvidosa. Mais do que simplesmente tematizar o adultério, o conto alerta as mulheres burguesas sobre os perigos de se ceder às tentações fora do casamento, uma vez que o amante de Eugênia acaba por 
abandoná-la no final. O caráter ousado do relato da viúva moça teria provocado reações violentas nos leitores, conforme sugere a polêmica na seção "a pedidos" do Correio Mercantil. Lúcia Granja (2008) e Jaison Crestani (2006) acreditam que Garnier tenha forjado um golpe publicitário a fim de atrair a atenção dos leitores em tempos de Guerra do Paraguai, que se desenvolveu entre os anos de 1865 e 1870 e provocou uma queda nas vendas do Jornal, conforme será analisado mais adiante.

\section{"Confissões de uma viúva moça": o ficcionista "no fio da navalha"}

"Confissões de uma viúva moça", assinado com o pseudônimo $J$., foi publicado em folhetim entre abril e junho de 1865, tendo sido incluído, posteriormente, na coletânea Contos Fluminenses, de 1870. A análise do conto nos permitirá depreender a existência de uma inegável relação estabelecida entre a narradora e o(a) leitor(a), seja ele(a) a leitora empírica do folhetim, seja ele(a) Carlota, amiga de Eugênia para quem as cartas são endereçadas. Cabe ressaltar que as relações com o leitor são construídas a partir de elementos fíccionais próprios do folhetim, tais como o corte narrativo, a propagação do suspense e o valor instrutivo da narrativa, que apela para a sensibilidade feminina a fim de construir uma espécie de "receituário básico" para o comportamento "decente" das leitoras. (PEREIRA, 2010, p. 389).

Em primeiro lugar, faz-se necessário considerar o papel do narrador em primeira pessoa. Neste conto, não se trata de um narrador e sim de uma narradora, o que aponta para a singularidade desta narrativa, uma vez que praticamente todos os narradores machadianos são homens. A este respeito, Cilene Margarete Pereira afirma o seguinte:

\footnotetext{
A opção narrativa de Machado revela a audácia do autor de, em uma época absolutamente restritiva à mulher, limitada por papéis secundários e precisos, darlhe voz. A configuração dessa narradora adquire uma força excepcional na obra machadiana, pois a mulher ao invés de silenciada - como serão outras versões da adúltera e de certas mulheres em sua ficção - se torna porta-voz das expectativas e frustrações femininas. (PEREIRA, 2010, p. 389).
}

Ao lançar mão de uma narradora ao invés de um narrador, Machado poderia também estar em busca de uma maior cumplicidade com a leitora empírica de seu conto, que, por conta do desnudamento da subjetividade feminina, poderia até se identificar com o relato de Eugênia. O foco narrativo em primeira pessoa, aliás, permite a penetração no universo emocional da mulher, em um relato resultante de uma memória marcada pela emoção e, ao mesmo tempo, pela racionalidade. Assim, a narrativa se torna uma espécie de diário íntimo, no qual a narradora combina emoção e cálculo como estratégia para cooptar sua leitora, conforme expresso no trecho abaixo: 
É tempo de contar-te este episódio de minha vida.

Quero fazê-lo por cartas e não por boca. Talvez corasse de ti. Deste modo o coração abre-se melhor e a vergonha não vem tolher a palavra nos lábios. Repara que eu não falo em lágrimas, o que é um sintoma de que a paz voltou ao meu espírito. (ASSIS, 2008, p. 114).

Estabelece-se, portanto, uma evidente tensão em um discurso impregnado pelas emoções e, ao mesmo tempo, pelo uso da racionalidade, uma vez que, dois anos após o ocorrido, Eugênia sente-se emocionalmente madura para poder contar a alguém a história de um deslize conjugal, algo que a envergonharia se fosse feito "por boca".

A história relatada na forma de gênero epistolar é outro dado a ser levado em consideração na análise da construção de relações textuais (e extratextuais) com o leitor. Além de ser um terreno propício para a exploração da subjetividade, o gênero carta permite uma relação muito próxima com o leitor, e, no caso do conto de Machado, com a amiga da narradora, que passa a ser sua principal interlocutora. Na visão de Lúcia Granja, isto faz com que os papéis de leitora empírica e amiga leitora se sobreponham, de forma que "Carlota, é claro, é a interlocutora que ocupa o lugar de todas as outras leitoras, as quais são, por sua vez, todas elas, possíveis interlocutoras de cartas reveladoras de uma amiga." (GRANJA, 2008, p. 22). O formato epistolar coincide com outro, que é também de fundamental relevância: o folhetim. Neste sentido, deve-se destacar o caráter metaficcional da narrativa, expresso na seguinte declaração de Eugênia: "As minhas cartas irão de oito em oito dias, de maneira que a narrativa pode fazer-te o efeito de um folhetim periódico semanal." (ASSIS, 2008, p. 114). O formato folhetinesco está, de fato, presente no conto, sendo que "os capítulos são cortados nos momentos de maior tensão, sendo interrompidos muitas vezes sem que se acabasse de se referir à ideia principal da carta, como espécie de prolongamento da narrativa." (PEREIRA, 2010, p. 389). Um exemplo disto é o encerramento da primeira carta, que corresponde ao primeiro capítulo: "Devo terminar esta. É o prefácio do meu romance, estudo, conto, o que quiseres. Não questiono sobre a designação, nem consulto para isso os mestres d'arte." (ASSIS, 2008, p. 114). Percebe-se, a partir da leitura deste trecho, que a narradora deixa a cargo do leitor a categorização do gênero textual de seu relato, o que mostra a importância da figura deste para a atribuição de significados à narrativa. Os comentários metaficcionais de Eugênia, portanto, modulam a recepção de seu relato, exercendo inegável influência sobre as interpretações e conjeturas de quem o lê.

$\mathrm{Na}$ transição para a segunda carta, opera-se o corte narrativo, que deixa o leitor em profunda expectativa em relação ao que virá a seguir. A carta é iniciada com considerações 
que, o leitor compreenderá mais tarde, funcionam como justificativas para as atitudes de Eugênia, como no excerto abaixo:

Minha casa era ponto de reunião de alguns rapazes conversados e algumas moças elegantes. Eu, rainha eleita pelo voto universal... de minha casa, presidia as reuniões familiares. Fora de casa, tínhamos os teatros animados, as partidas das amigas, mil outras distrações que davam à minha vida certas alegrias exteriores em falta das íntimas, que são as únicas verdadeiras e fecundas.

Se eu não era feliz, era alegre.

E aqui vai o começo do meu romance. (ASSIS, 2008, p. 115).

Com base nestas informações, percebe-se que Machado já começa a articular a denúncia que funciona como mote central de sua narrativa: a insatisfação feminina com a vida conjugal, algo que deveria ser muito frequente em uma sociedade patriarcal que propalava o casamento por conveniências, realizado, na maioria das vezes, sem amor. Torna-se clara a futilidade que norteia a vida do casal, baseada quase que exclusivamente em reuniões com "rapazes conversados e moças elegantes", eventos que conferem à vida de Eugênia a alegria que, ela admite, falta em sua vida particular. Ela chega até mesmo a negar que era feliz, o que sugere a enorme frustração amorosa que abrirá espaço para as investidas de um estranho. Ao iniciar seu relato desta forma, a narradora tenta angariar a simpatia tanto do(a) leitor(a) empírico(a) quanto de sua interlocutora, talvez com o intuito de suavizar a suposta amoralidade de sua narrativa. Isto se observa nos primeiros trechos da primeira carta, em que ela afirma ter se isolado por dois anos em Petrópolis, como se estivesse se punindo pelo que fez: "Estes dois anos são nulos na conta de minha vida; foram dois anos de tédio, de desespero íntimo, de orgulho abatido, de amor abafado.” (ASSIS, 2008, p. 114). Além disso, constata-se o teor utilitário assumido pela narração de Eugênia, que considera sua história um alerta para "as nossas amigas inexperientes", rogando a Carlota: "Mostra-lhes estas cartas; são folhas de um roteiro que se eu tivera antes, talvez, não houvesse perdido uma ilusão e dois anos de vida." (ASSIS, 2008, p. 114). Desta forma, pode-se inferir que Machado de Assis, por meio da narração de uma mulher desiludida mas já refeita emocionalmente desta experiência, estivesse tentando alertar as leitoras do Jornal das Famílias a respeito não só dos infortúnios da vida de casada, mas das consequências advindas da não-aceitação das condições impostas pelo casamento, que podem ser piores do que qualquer matrimônio por conveniência.

O encontro com o misterioso homem se dá no teatro Lírico, lugar que Eugênia insiste em frequentar a despeito da recusa do marido: "Eu tinha certa superioridade sobre o espírito de meu marido. O meu tom imperioso não admitia recusa; meu marido cedeu a despeito de tudo, e à noite fomos ao teatro Lírico." (ASSIS, 2008, p. 115). Este trecho nos revela a 
submissão do marido às vontades da esposa, permitindo-nos caracterizá-lo como uma pessoa inexpressiva e até mesmo nula. É interessante inclusive observar que o marido não é sequer nomeado ao longo da narrativa, o que remete a um apagamento de sua identidade. Talvez seja esta indiferença a causadora do interesse de Eugênia por um homem que se impõe pela ousadia não observada em seu marido:

\footnotetext{
Somos todas vaidosas da nossa beleza e desejamos que o mundo inteiro nos admire. É por isso que muitas vezes temos a indiscrição de admirar a corte mais ou menos arriscada de um homem. Há, porém, uma maneira de fazê-lo que nos irrita e nos assusta; irrita-nos por impertinente, assusta-nos por perigosa. É o que se dava naquele caso.

O meu admirador insistia de tal modo que me levava a um dilema: ou ele era vítima de uma paixão louca, ou possuía a audácia mais desfaçada. Em qualquer dos casos não era conveniente que eu animasse as suas adorações. (ASSIS, 2008, p. 117).
}

O trecho acima também revela duas características fundamentais da personalidade da narradora: a vaidade e a curiosidade, que acabam levando-a a corresponder, sem querer, o descarado flerte do estranho, ainda que reconheça o perigo de fazê-lo. Estabelece-se, portanto, uma ambiguidade que acompanhará Eugênia ao longo de toda a sua narrativa, assentada em um dilema moral entre ceder às investidas insistentes do homem e preservar um casamento que, apesar de infeliz, lhe dá segurança. Na visão de Lúcia Granja, "no lugar de uma amoralidade insinuada, está, na verdade, a história de uma esposa virtuosa." (GRANJA, 2008, p. 23). O flerte insistente do homem, por sua vez, remete a um suposto caráter dominador, que reduz a mulher à condição de objeto a ser olhado e admirado a despeito de sua vontade e de seu estado civil. A preocupação da narradora é tão grande que ela resolve se isolar da vida social por algum tempo, com o objetivo de salvar-se "de uma preocupação que podia ser-me fatal." (ASSIS, 2008, p. 118). Tem-se, com esta declaração, uma prova de que Eugênia tinha noção das conseqüências advindas de um caso extraconjugal, o que angaria ainda mais simpatia por parte do(a) leitor(a), pois não se trata de uma mulher leviana e sim, de uma mulher honesta.

A paz da narradora tem seu fim quando ela recebe uma carta de seu admirador secreto, o que intensifica ainda mais a aura de mistério em torno dele:

\footnotetext{
Não se surpreenda, Eugênia; este meio é o do desespero, este desespero é o do amor. Amo-a e muito. Até certo tempo procurei fugir-lhe e abafar este sentimento; não posso mais. Não me viu no teatro Lírico? Era uma força oculta e interior que me levava ali. Desde então não a vi mais. Quando a verei? Não a veja embora; paciência; mas que o seu coração palpite por mim um minuto em cada dia, é quanto basta a um amor que não busca nem as venturas do gozo, nem as galas da publicidade. Se a ofendo, perdoe um pecador; se pode amar-me, faça-me um deus. (ASSIS, 2008, p. 118).
} 
Para Cilene Margarete Pereira, a carta de Emílio contém figurações poéticas, entusiastas e românticas que nada mais são do que técnicas de persuasão usadas com a finalidade de envolver a mulher no jogo amoroso. (PEREIRA, 2010, p. 396-397). Esta, por sua vez, torna-se um espelho de seu sedutor ao também lançar mão de cartas para relatar a sua história, o que nos permite inferir que elas são construídas para seduzir o seu leitor. (PEREIRA, 2010, p. 387-388). Interessante observar que a narradora havia decorado o conteúdo da carta, uma vez que a queimara em seu gabinete, no momento em que seu marido entrava pela porta:

\footnotetext{
Quando a última faísca do papel enegreceu e voou, senti passos atrás de mim. Era meu marido.

Tive um movimento espontâneo: atirei-me em seus braços.

Ele abraçou-me com certo espanto.

E quando meu abraço se prolongava senti que ele me repelia com brandura dizendome:

- Está bom, olha que me afogas!

Recuei.

Entristeceu-me ver aquele homem, que podia e devia salvar-me, não compreender, por instinto ao menos, que se eu o abraçava tão estreitamente era como se me agarrasse à ideia do dever.

Mas este sentimento que me apertava o coração passou por um momento para dar lugar a um sentimento de medo. As cinzas da carta ainda estavam no chão, a vela conservava-se acesa em pleno dia; era bastante para que ele me interrogasse.

Nem por curiosidade o fez!

Deu dois passos no gabinete e saiu.

Senti uma lágrima rolar-me pela face. Não era a primeira lágrima de amargura. Seria a primeira advertência do pecado? (ASSIS, 2008, p. 120).
}

Torna-se claro que a postura do marido, somada à vaidade da viúva moça e ao seu descontentamento com a vida conjugal, irão agir em favor de Emílio, que encontra terreno livre para exercer sua sedução. A partir do recebimento da carta, Eugênia não é mais a mesma pessoa, pois a imaginação e o mistério atiçam a sua curiosidade: "a luta do dever e da imaginação é cruel e perigosa para os espíritos fracos. Eu era fraca. O mistério fascinava a minha fantasia." (ASSIS, 2008, p. 120). A indiferença de seu cônjuge torna-se ainda mais evidente do terceiro capítulo, em que a narradora descreve uma reunião em sua casa na qual a ausência dele "não era notada nem sentida, visto que, apesar de franco cavalheiro como era, não tinha o dom particular de um conviva para tais reuniões.” (ASSIS, 2008, p. 120-121). Trata-se, portanto, de um homem inexpressivo tanto social quanto afetivamente, pelo menos dentro da perspectiva de Eugênia, que, com sua narração, "marca o desconforto da mulher e sua inadequação aos princípios postulados do casamento.” (PEREIRA, 2010, p. 401). Neste sentido, o texto machadiano problematiza a experiência do matrimônio, chamando a atenção para a necessidade de se questionar os papéis da mulher e do homem no interior de uma 
relação em que o marido se torna o responsável indireto pelo flerte de sua esposa com um desconhecido.

A surpresa de Eugênia é enorme quando ela se depara com Emílio, acompanhado por seu marido, na sala de sua casa. O rapaz acaba por cativar a todos com seu charme e sua conversa de homem culto e recém-chegado da Europa: "Soubemos então que Emílio era um provinciano filho de pais opulentos, que recebera uma esmerada educação na Europa, onde não houve um só recanto que não visitasse." (ASSIS, 2008, p. 121). A educação europeia confere ao personagem ares cosmopolitas que atraem a atenção de todos, inclusive do marido de Eugênia, que se empolga bastante com o desconhecido: "É uma pérola, não é? Foi-me apresentado no escritório há dias; simpatizei logo; parece ser dotado de boa alma, é vivo de espírito e discreto como o bom senso. Não há ninguém que não goste dele...' (ASSIS, 2008, p. 122). Tem-se, portanto, uma ameaça latente ao casamento que é plenamente ignorada pelo marido, o que fragiliza Eugênia e a expõe ainda mais aos artifícios do sedutor. Quase ao término do terceiro capítulo, ela demonstra estar consciente de sua condição:

\begin{abstract}
Se meu marido tivesse em mim uma mulher, e se eu tivesse nele um marido, minha salvação era certa. Mas não era assim. Entramos no nosso lar nupcial como dois viajantes estranhos em uma hospedaria, e aos quais a calamidade do tempo e a hora avançada da noite obrigam a aceitar pousada sob o teto do mesmo aposento.

Meu casamento foi resultado de um cálculo e de uma conveniência. Não inculpo meus pais. Eles cuidavam fazer-me feliz e morreram na convicção de que o era.

Eu podia, apesar de tudo, encontrar no marido que me davam um objeto de felicidade para todos os meus dias. Bastava para isso que meu marido visse em mim uma alma companheira de sua alma, um coração sócio do seu coração. Não se dava isto; meu marido entendia o casamento ao modo da maior parte da gente; via nele a obediência às palavras do Senhor do Gênesis. (ASSIS, 2008, p. 123).
\end{abstract}

A insatisfação feminina é trazida à tona, servindo como estratégia para angariar, mais uma vez, a simpatia e a cumplicidade da leitora do Jornal das Famílias, além de denunciar, de maneira bastante clara, as consequências dos casamentos arranjados na sociedade brasileira oitocentista. O adultério vem a ser uma destas consequências, transformando-se, para Cilene Margarete Pereira, em uma "forma de resposta à nulidade do papel matrimonial do homem ou à distância que este ocupa em relação ao ideal da mulher.” (PEREIRA, 2010, p. 402). Tal distância é enfatizada na fala de Eugênia, no momento em que ela diz que o marido, assim como os outros, via no casamento uma obediência às palavras de deus, ao invés de percebê-lo como "objeto de felicidade" e de realização pessoal. Torna-se, portanto, evidente que as expectativas de marido e mulher estão desencontradas, uma vez que Eugênia esperava mais do casamento, ao passo que seu marido agia em conformidade com regras sociais, morais e religiosas. Daí a frustração da mulher, que se transforma em um ser duplo, pois, ao mesmo 
tempo em que rompe com os valores morais da sociedade, "se vê presa a certas imposições sociais que a impedem de dar um passo à frente.” (PEREIRA, 2010, p. 405).

Não se pode deixar de ressaltar que a infidelidade conjugal é um dos temas mais presentes na obra de Machado de Assis, em especial em Dom Casmurro e Memórias póstumas de Brás Cubas. Havia, no século XIX, uma moral disciplinadora que condenava o adultério feminino, alegando que ele desarticulava a ordem familiar e colocava a paternidade em dúvida. A análise de "Confissões de uma viúva moça" revela as possíveis causas da traição, que seria resultado da falta de realização emocional da mulher e da indiferença do homem, que permite a entrada de um estranho em sua casa e, consequentemente, em sua vida. Neste sentido, é quase impossível não se recordar de Bento Santiago, que passa a suspeitar que Capitu o traíra com Escobar, seu amigo inseparável dos tempos de seminário. Também nos vem à lembrança a figura de Brás Cubas, que trava relações amigáveis com Lobo Neves mas mantém um caso amoroso com sua esposa, Virgília. Tanto Escobar como Brás Cubas são dissimulados e manipuladores, características que também podem ser identificadas em Emílio. Este continua a frequentar a casa de Eugênia sem dar mostras de seu interesse por ela, situação esta que se prolonga por alguns meses, até surgir a oportunidade de ficarem a sós. Nesta ocasião, o elegante rapaz declara o seu suposto amor pela narradora:

- Oh! eu bem sei a que me exponho. Vejo como este amor é culpado. Mas que quer? É fatalidade. Andei tantas léguas, passei à ilharga de tantas belezas, sem que o meu coração pulsasse. Estava-me reservada a ventura rara ou o tremendo infortúnio de ser amado ou desprezado pela senhora. Curvo-me ao destino. Qualquer que seja a resposta que eu possa obter, não recuso, aceito. Que me responde? (ASSIS, 2008, p. 126).

Neste trecho, Emílio mais uma vez lança mão de artifícios românticos para convencer Eugênia de seu amor, afirmando que sua felicidade está nas mãos dela. Ao exigir uma resposta, o rapaz dissimula uma relação de dependência entre os dois, apelando, metafórica e implicitamente, para as capacidades leitoras de Eugênia, que se revela, ao fim e ao cabo, uma ingênua leitora de seus atos e de sua aproximação. (PEREIRA, 2010, p. 413). Mais por medo do que por rejeição, ela pede que ele se retire de sua casa, cedendo, contudo, à manipulação contida naquela declaração de amor:

\footnotetext{
Até então eu não tinha visto o amor senão nos livros. Aquele homem parecia-me realizar o amor que eu sonhara e vira descrito. A ideia de que o coração de Emilio sangrava naquele momento despertou em mim um sentimento vivo de piedade. A piedade foi um primeiro passo. (ASSIS, 2008, p. 128).
}

Ela chega até mesmo a considerar que foi muito severa com o rapaz, sensação que se confirma quando, no quinto capítulo, descobre que Emílio está doente. Tal doença, na 
realidade, é a sugestão de uma tentativa de suicídio, papel certamente emprestado de Werther, personagem principal de um dos romances mais emblemáticos da literatura ocidental. A representação é bem sucedida, uma vez que a narradora é enredada no jogo de sedução, encenado com lágrimas e falsas ameaças de sofrimento. Mesmo apaixonada, no entanto, Eugênia recusa-se a fugir com Emílio, dando a seguinte justificativa: "desejo ficar a seus olhos a mesma mulher, amorosa é verdade, mas até certo ponto... pura." (ASSIS, 2008, p. 133). Mesmo cometendo adultério, Eugênia se preocupa em manter a sua honra, o que remete à cisão que se opera na personalidade da viúva moça, dividida entre viver uma nova paixão e manter um casamento de aparências. A solução para este conflito parece se esboçar com a morte do marido, que libera a narradora das exigências matrimoniais e permite que ela disponha de si mesma. Para Lúcia Granja, o fato de Eugênia ser "uma viúva moça" tem implicações diretas na construção do gênero folhetim, conforme a citação abaixo:

\footnotetext{
Pensando que uma viúva moça corresponde a uma das (raras) formas de autonomia e liberdade da mulher naquela sociedade, e que Eugênia, dentro da narrativa, se põe a narrar querendo que seu relato seja lido como ficção e no formato "folhetim", temos aqui uma interessante intersecção entre personagem, narrativa e liberdade, assim como entre narrador, ficção e folhetim. (GRANJA, 2008, p. 25).
}

De fato, só depois de se tornar viúva e de se isolar por dois anos na serra fluminense é que a narradora toma coragem de relatar à amiga sua desventura amorosa, o que ratifica não só as ideias de Granja como também a existência das amarras da sociedade patriarcal, onde apenas as viúvas podiam usufruir de uma real liberdade. A viuvez se afigura, portanto, como uma justificativa social para a experiência da nova paixão, o que nos mostra que Machado de Assis estava bastante atento não só às regras do mercado matrimonial, mas também aos dispositivos sociais que governavam as relações afetivas e sexuais. Daí o apelo incontestável de "Confissões de uma viúva moça" junto às leitoras do Jornal das Famílias, que poderiam ter vivenciado experiência semelhante ou conhecer alguém que a vivenciara, corroborando, assim, o pacto ficcional entre leitor e obra literária.

Ao enviuvar, Eugênia se considera moral e socialmente livre para viver a sua paixão, mas descobre que Emílio vai partir da corte. É a partir da leitura desta carta que a narradora toma conhecimento da verdadeira índole do rapaz: "Uma união contigo seria para mim o ideal da felicidade se eu não fosse homem de hábitos opostos ao casamento. Adeus. Desculpa-me, e reza para que eu faça boa viagem. Adeus. Emílio.” (ASSIS, 2008, p. 135). Torna-se claro, neste momento da narrativa, o descompasso existente entre o amor fulminante anteriormente declarado a Eugênia e a informação de que Emílio era, na realidade, apenas um sedutor. 
Confirma-se, assim, a incapacidade feminina em fazer uma leitura adequada das atitudes deste homem, incapacidade esta que provoca uma confusão emocional que é, mais tarde, superada:

\begin{abstract}
Mas, perguntava eu, como é que este homem, que parecia amar-me tanto, recusou aquela de cuja honestidade podia estar certo, visto que pôde opor uma resistência aos desejos de seu coração? Hoje vejo que não era; Emílio era um sedutor vulgar e só se diferençava dos outros em ter um pouco mais de habilidade do que eles.

Tal é a minha história. Imagina o que sofri nestes dois anos. Mas o tempo é um grande médico: estou curada.

$\mathrm{O}$ amor ofendido e o remorso de haver de algum modo traído a confiança de meu esposo fizeram-me doer muito. Mas eu creio que caro paguei o meu crime e achome reabilitada perante a minha consciência. (ASSIS, 2008, p. 135-136).
\end{abstract}

Ao término da narrativa, Eugênia faz uma mea culpa a fim de, mais uma vez, cativar o seu leitor, mostrando ter consciência acerca do erro que cometera. É neste momento em que a viúva moça, nas palavras de Cilene Margarete Pereira, se transforma em uma "narradora utilitária", pois deixa claro que seu relato tem um "ensinamento moral a transmitir." (PEREIRA, 2010, p. 391). O valor educacional do texto literário é salientado por Sandra Vasconcelos em seu estudo sobre o romance inglês do século XVIII:

Diante do reduzido acesso feminino à educação formal, são os romances e periódicos que vão preencher a lacuna e cumprir o papel de importante fonte de educação para a maioria das mulheres. O romance passa a funcionar, graças ao zelo didático dos romancistas e aos propósitos morais que alegam ter, como um poderoso instrumento pedagógico que visa à reforma dos costumes e maneiras. (VASCONCELOS, 2002, p. 141-142).

Apesar de ter sido escrito no século XIX, o conto de Machado faz jus às afirmações acima, ainda mais se considerarmos o veículo no qual foi publicado. Daí a importância de se analisar o papel do leitor na significação de "Confissões de uma viúva moça”, uma vez que tal papel, além de construído pela própria narradora, foi problematizado em uma polêmica no jornal Correio Mercantil. Raimundo Magalhães Jr. chega a instigantes conclusões a respeito do assunto:

[...] Machado de Assis esteve envolvido numa falsa polêmica, travada em "apedidos", isto é, na seção paga do Correio Mercantil e por sua vez, no Diário do Rio de Janeiro, a que Machado de Assis pertencia. Um exame aberto dessa polêmica levaria qualquer observador medianamente arguto a descobrir que tudo não passava de um simples artifício publicitário. (MAGALHÃES JÚNIOR, 1981, p. 321).

O "artifício publicitário" teria sido usado pelo editor Garnier e pelo próprio Machado de Assis a fim de atrair a atenção dos leitores, que não seria mais a mesma por conta da queda de vendas do Jornal das Famílias. Esta teria sido provocada pela Guerra do Paraguai, que se iniciara em 1865, mesmo ano de publicação de "Confissões de uma viúva moça". A primeira investida de "O Caturra" aparece no dia primeiro de abril, logo após a publicação dos dois 
primeiros capítulos da narrativa, os quais, conforme já analisado, parece esboçar o princípio do adultério e a indiferença do marido de Eugênia:

Jornal das Famílias

$[\ldots]$

No último número deste jornal, que se diz das famílias, e cujo programa já vai se afastando sofrivelmente, enceta-se a publicação de um romancito sob o título Confissões de uma viúva moça.

Pela amostra do pano desde já se pode conjeturar de que magnificência será o vestido que trata-se de expor à atenção das jovens, que têm um dia de serem esposas e mães de família, isto é, daquelas que bem deverão compreender qual a verdadeira missão dos filhos, e os legítimos gozos ocorrentes que suavizam os frequentes cuidados de respeitável mãe de família. Para os pais de família, pés de boi, os que têm a esquisitice de verem a realidade deste mundo pelo prisma rococó escrevemos estas ligeiras linhas, pedindo-lhes que façam companhia às suas filhas na apreciação de tão edificantes escritos, tão harmoniosos como os esplendores deste século reformista. (O CATURRA apud MASSA, 1965, p. 210).

O comentário teve resposta no dia 2 de abril, quando $J$, na realidade Machado de Assis, rebateu da seguinte forma: "Felizmente, basta ler o primeiro capítulo para ver a malignidade d'O Caturra. Protesta-se contra a caturrice, e fiquem descansados os pais de família: o autor das Confissões respeita, mais que ninguém, a castidade dos costumes." (J., apud MASSA, 1965, p. 211). Estabelece-se, desta forma, um descompasso entre a interpretação do polemista e o que está realmente escrito no conto, uma vez que, para Lúcia Granja, "nada havia nos dois primeiros capítulos que viesse a fazer apologia de um vício moral." (GRANJA, 2008, p. 25). A polêmica teria continuidade no mês de maio, mais especificamente no dia primeiro, quando "O Caturra", em novo artigo publicado no Correio Mercantil, demonstra, mais uma vez, preocupação com a castidade das famílias e com uma suposta liberdade exagerada de imprensa que a publicação das "Confissões" demonstrou existir. Tal liberdade estaria relacionada a alguns aspectos do enredo, entre eles a paixão de Eugênia por outro homem e a iniciativa de se isolar na serra fluminense em pleno inverno. No entanto, vale ressaltar que tal liberdade não é conquistada à revelia de quaisquer fatores sociais, sendo apenas possível a partir do momento em que a personagem se torna viúva. Assim sendo, confirma-se a "caturrice" do polemista, o que nos dá a entender que o irônico comentário foi talvez escrito com o objetivo de provocar não só os leitores, mas o próprio Machado, que responde à altura, exigindo uma leitura adequada de sua narrativa.

No dia 2 de maio, o escritor assume sua identidade em mais uma de suas respostas às reclamações de "O Caturra": "Sou o autor do romance que, com este título, publica atualmente o Jornal das Famílias. Peço ao Sr. Caturra que aguarde o resto do escrito para 
julgar da sua moralidade - sem o que, qualquer discussão será inútil.” (ASSIS, apud MASSA, 1965, p. 211). Com esta declaração, Machado elegantemente desqualifica a leitura do misterioso polemista, reiterando a impossibilidade de se fazer uma interpretação moralista sem ler o conto na íntegra. Em 4 de maio, "O Caturra" responde o seguinte: "releve-nos o Sr. Machado de Assis essa rigidez do nosso conceito; nem todos a terão, e é provável mesmo que estejamos em ridícula minoria." (O CATURRA, apud MASSA, 1965, p. 214). Estes comentários se adequam perfeitamente ao pseudônimo adotado pelo comentarista, uma vez que "caturra" significa "teimoso", "rabugento" e "agarrado a velhos hábitos". (GRANJA, 2008, p. 26). Neste sentido, cabe uma pergunta: não seria o "caturra" o próprio Garnier, ou alguém de fora do grupo de jornalistas do Jornal das Famílias, ou simplesmente um moralista realmente preocupado com a manutenção da integridade da família burguesa? Não há, na crítica machadiana, um consenso a respeito disto; o que há é, conforme já dito, a suspeita de que a polêmica tenha sido forjada, o que mostra a habilidade tanto do escritor quanto de seu editor em prever e até mesmo, manipular a recepção de uma narrativa. É bem possível que Garnier, consciente da temática aparentemente subversiva de "Confissões de uma viúva moça", tenha tentado atrair a atenção dos seus leitores, convocando, também, o próprio Machado para defender o seu texto e amenizar quaisquer reações violentas por parte do público leitor. Assim sendo, o que o "golpe publicitário" revela é, acima de tudo, "a consciência das formas literárias em sua relação com o seu veículo e seu público", evidenciando a capacidade machadiana de imaginar outras vozes e de lançar mão de tais vozes para dinamizar a recepção de sua narrativa. (GRANJA, 2008, p. 27).

Com base em tudo o que foi exposto, pode-se interpretar "Confissões de uma viúva moça" como um conto que, além de tematizar alguns aspectos da condição feminina na sociedade do século XIX, nos permite analisar a construção das relações entre autor, obra literária e leitor, relação esta que é construída dentro do texto e pelo texto, por meio das técnicas folhetinescas que criam suspense e aumentam a expectativa daquele que lê. Isto é o que parece fazer com que Eugênia passe de "personagem seduzida" a "narradora sedutora, que usa a sedução romanesca para alcançar sua leitora e compreender-se melhor.” (PEREIRA, 2010, p. 415). Garnier, assim como Machado, certamente não estava imune a esta sedução, pois lançou mão dela para movimentar leituras e interpretações distintas, permitindo-nos aprofundar a questão da polêmica para além da queda nas vendas causada pela Guerra do Paraguai. Temos, desta maneira, evidências de que Machado de Assis, mesmo antes da fase 
realista, estava atento ao seu público leitor e às mais diversas formas de recepção literária, algo que seria, mais tarde, largamente destacado e explorado em sua literatura.

\section{Referências}

ASSIS, Machado de. Contos Fluminenses. São Paulo: Martin Claret, 2008.

CRESTANI, Jaison. A colaboração de Machado de Assis no Jornal das Famílias: subordinações e subversões. Patrimônio e memória, São Paulo, n. 1, v. 2, p. 154-183, 2006. Disponível em: http://pem.assis.unesp.br/index.php/pem/article/view/109 Acesso em: 01 fev. 2014.

FARIAS, Virna Lúcia Cunha de. Machado de Assis na imprensa do século XIX: práticas, leitores e leituras. 238f. Tese (Doutorado em Letras) - Centro de Ciências Humanas, Letras e Artes, Universidade Federal da Paraíba, 2013.

GRANJA, Lúcia. Novas confissões sobre um conto polêmico de Machado de Assis. Machado de Assis em linha, São Paulo: n. 1, p. 19-28, jun. 2008. Disponível em: http://machadodeassis.net/download/numero01/num01artigo03.pdf Acesso em: 01 fev. 2014.

GUIMARÃES, Hélio de Seixas. Os leitores de Machado de Assis: o romance machadiano e o público de literatura no século XIX. São Paulo: EDUSP, 2004.

MAGALHÃES JÚNIOR, Raimundo. Vida e obra de Machado de Assis. Rio de Janeiro: Civilização Brasileira, 1981.

MASSA, Jean Michel (Org.). Dispersos de Machado de Assis. Rio de Janeiro: INL, 1965.

PEREIRA, Cilene Margarete. "Confissões de uma viúva moça" e a educação sentimental da mulher machadiana. Revista Travessias, Cascavel, n. 1, v. 4, p. 385-417, 2010. Disponível em: http://e-revista.unioeste.br/index.php/travessias/article/view/3606/2863 Acesso em: 01 fev. 2014.

VASCONCELOS, Sandra Guardini. Dez lições sobre o romance inglês no século XVIII. São Paulo: Boitempo Editorial, 2002.

[Recebido em fevereiro de 2014 e aceito para publicação em agosto de 2014] Machado de Assis and the periodic press: an analysis of "Confissões de uma viúva
moça"

Abstract: This articles's aim is to analyze the short story "Confissões de uma viúva moça", published by Machado de Assis as a serialized novel in Jornal das Familias. The story gives us some evidence on Machado's actuation in Rio de Janeiro's periodic press in the beginning of his literary career, as well as the ways in which he built a relationship with his readers, being them real or fictional. Firstly, there will be a brief theoretical discussion in relation to the status of the newspaper and the formation of the reading public in the nineteenth-century Brazilian society, seeking to understand the role of the newspapers and journals and the circulation of literary texts, as well as the profile of the readers of Jornal das Familias. Secondly, the short story will be analyzed, in order to show how the relationship between the writer and the reader is constructed, considering the communication vehicle in which it is 
published. Finally, the polemic in Correio Mercantil will be discussed, in order to show how Machado and his editor built a relationship with the readers of Jornal das Familias.

Keywords: Journal. Serialized novel. Reader.

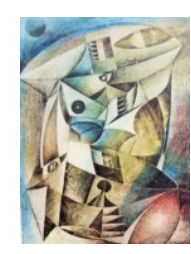

